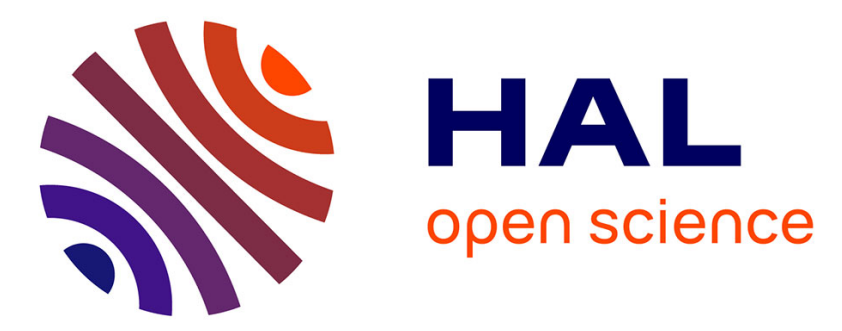

\title{
Direct Immunological Detection of Wood Cell Wall Polysaccharides after Microwave- Assisted Ionic Liquid Disruption
}

Idelette Plazanet, Rachida Zerrouki, Sabine Lhernould, Christian Breton, Guy Costa

\section{To cite this version:}

Idelette Plazanet, Rachida Zerrouki, Sabine Lhernould, Christian Breton, Guy Costa. Direct Immunological Detection of Wood Cell Wall Polysaccharides after Microwave- Assisted Ionic Liquid Disruption. Journal of Glycobiology, 2015, 4 (1), 4 p. 10.4172/2168- . hal-02630122

\section{HAL Id: hal-02630122 \\ https://hal.inrae.fr/hal-02630122}

Submitted on 27 May 2020

HAL is a multi-disciplinary open access archive for the deposit and dissemination of scientific research documents, whether they are published or not. The documents may come from teaching and research institutions in France or abroad, or from public or private research centers.
L'archive ouverte pluridisciplinaire $\mathbf{H A L}$, est destinée au dépôt et à la diffusion de documents scientifiques de niveau recherche, publiés ou non, émanant des établissements d'enseignement et de recherche français ou étrangers, des laboratoires publics ou privés. 


\title{
Direct Immunological Detection of Wood Cell Wall Polysaccharides after Microwave-Assisted Ionic Liquid Disruption
}

\author{
Plazanet I', Zerrouki R ${ }^{1}$, Lhernould $\mathbf{S}^{1}$, Breton $\mathbf{C}^{2}$ and Costa $\mathbf{G}^{1 *}$, \\ ${ }^{1}$ Laboratoire de Chimie des Substances Naturelles (EA 1069) Faculté des Sciences et Techniques, 123 Avenue Albert Thomas, F-87060 Limoges Cedex, France \\ ${ }^{2}$ INRA Val de Loire, UR 0588 Amélioration Génétique et Physiologie Forestière, 2163 avenue de la pomme de pin, CS 40001 Ardon, 45075 Orléans cedex 2, France
}

\begin{abstract}
We present here a new cell wall polysaccharide analysis method based on the fast and efficient ionic liquid solubilization of wood samples followed by direct immunological detections of their polysaccharide contents. To reduce both the time and the temperature of the analysis, wood powder samples are first totally disrupted in 1-ethyl3-methylimidazolium under controlled microwave irradiation. The solubilized extracts are then directly spotted onto nitrocellulose membranes in order to specifically detect their polysaccharide contents with a set of monoclonal antibodies. Compared to the long sequential method classically used for biomass analysis, the technique described in this article allows the simultaneous treatments of higher numbers of smaller samples. It represents an interesting toolkit to rapidly screen various biomass resources for their polysaccharide contents.
\end{abstract}

Keywords: Biomass; Biofuel; Hemicelluloses; Pectins; 1-Ethyl-3Methylimidazolium Acetate; Immunoassay

Abbreviations: mAb: Mab Monoclonal Antibodies; IL: Ionic Liquid

\section{Introduction}

Because plant cell wall is a dynamic structure with multiple functions, the knowledge of its molecular composition and organization represents a great challenge for plant physiologists. Plant cell walls are composed of several layers including the middle lamella, the primary cell wall and for some cells a third layer, the secondary wall. The middle lamella, rich in pectic substances, provides intercellular cohesion. The primary wall consists of a complex network of polysaccharides (about 90\%) and proteins (about 10\%) [1]. In all cells, rigid cellulose microfibrils are embedded in a matrix of non-cellulosic polysaccharides and pectins. The secondary wall of specialized cells is mainly composed of hemicellulose and cellulose crystalline microfibrils organized in concentric layers parallel to each other. It is reinforced by lignin, a phenolic polymer [1]. The middle lamella, the primary and the secondary wall contain molecules that interact with each other through many chemical bonds, making difficult their purification and analysis. Long and tedious physical [2], chemical and enzymatic methods [3] are usually used to purify each kind of cell wall component. As biofuel resources, soluble polysaccharides are then analyzed by GC-MS after derivatization [4-6] or more recently by probing them on membranes or microarrays [7-8]. Regardless of the method, the disorganization of the wall polymers, with various extraction agents represents an important prerequisite to the release and analysis of cell wall polysaccharides. As classical extraction processes are time consuming (at least one week) and require relatively large amounts of starting material (several grams), some new approaches such as wood biomass solubilization by ionic liquids could be advantageously developed to fasten and facilitate their analysis.

Ionic liquids (ILs) have been extensively used as solvent for biofuel production. They are low melting point salt solutions, that remain in a liquid state at temperatures below the boiling point of water or even room temperature [9]. Among them, 1-butyl-3-methylimidazolium chloride ([BMIM]-Cl) was shown to dissolve cellulose at relatively high concentrations leading to the creation of a new class of solvents for it [10]. More recently, 1-ethyl-3-methylimidazolium acetate ([EMIM]$\mathrm{OAc})$ was shown to be more efficient than [BMIM]-Cl to dissolve wood and microwave pretreatment decreased the time necessary to obtain a complete dissolution of the biomass [11]. Based on these observations, we investigated the use of [EMIM]-OAc coupled with microwave irradiation to solubilize lignocellulosic materials in order to overcome the particularly long and complex methods generally used for cell wall polysaccharides extraction. Ultimately, the originality of the method described here also relies on the final polysaccharide immunological detection technique, (i.e.: dot blot immunoassays) directly used on IL solubilized wood polysaccharides instead of resolubilized buffered extracts. Our results demonstrate that these conditions allow the release of plant cell wall polysaccharides still recognizable by specific monoclonal antibodies indicating that the extraction process preserves, at least partially, some of their structures. In the end and most importantly, the amounts of material needed for polymer identification are reduced by $95 \%$ and the timespan for analysis by [2]

\section{Materials and Methods}

\section{Wood sampling}

Wood samples (1-2 cm thick disks) were collected at $1.3 \mathrm{~m}$ from the trunk of a 20 year-old walnut tree (Juglans nigra) from our nursery and felled in july. Wood disks were directly frozen in liquid nitrogen and lyophilized (Alpha 1-4 LSC freeze-dryer, Christ). Once the bark removed, the inner part of the disks was grounded into a fine powder $(<250 \mu \mathrm{m})$ with a Dangoumeau steel ball mill. Wood powder samples were then homogenized and stored in dry atmosphere until analysis.

\section{IL and microwave wood treatments}

Fifty $\mathrm{mg}$ of wood powder were added to $1 \mathrm{~mL}$ of 1-ethyl-3methylimidazolium acetate ([EMIM]-OAc) (Sigma Aldrich) (Protocol

*Corresponding author: Dr. Costa G, Laboratoire de Chimie des Substances Naturelles (EA 1069) Faculté des Sciences et Techniques, 123 Avenue Albert Thomas, 87060 Limoges Cedex, France, Tel: 33(0) 555457 216; Fax: 33(0) 555457765 E-mail: guy.costa@unilim.fr

Received November 28, 2014; Accepted March 30, 2015; Published April 05, 2015

Citation: Plazanet I, Zerrouki R, Lhernould S, Breton C, Costa G (2015) Direct Immunological Detection of Wood Cell Wall Polysaccharides after MicrowaveAssisted Ionic Liquid Disruption. J Glycobiol 4: 115. doi:10.4172/2168 958X.1000115

Copyright: @ 2015 Plazanet I et al. This is an open-access article distributed under the terms of the Creative Commons Attribution License, which permits unrestricted use, distribution, and reproduction in any medium, provided the original author and source are credited. 
I and II) or $500 \mathrm{mg}$ to $10 \mathrm{ml}$ of [EMIM]-OAc (Protocol III). Four wood powder IL disruption protocols involving different heat and microwave treatments were tested. Protocol (I) consisted of a $2 \mathrm{~h}$ incubation at $80^{\circ} \mathrm{C}$ followed by an overnight treatment at $55^{\circ} \mathrm{C}$ in an oil bath. The three other treatments included different microwave activations performed with an Ethos 1600 MicroSynth reactor (Milestone,USA). Temperatures of the irradiated samples were controlled with a fiber optic thermometer (Ethos ATC-FO). Between each irradiation step, the extracts were cooled down to room temperature. In protocol (II) the wood suspension $(1 \mathrm{ml})$ was microwaved three times $(300 \mathrm{~W}, 2 \mathrm{~min}$, $80^{\circ} \mathrm{C}$ upper limit temperature). In condition (III), the samples $(10 \mathrm{ml})$ were irradiated twice $\left(300 \mathrm{~W}, 30 \mathrm{sec}, 50^{\circ} \mathrm{C}\right.$ upper limit temperature) and twice again $\left(300 \mathrm{~W}, 50 \mathrm{sec}, 50^{\circ} \mathrm{C}\right.$ upper limit temperature). For the last condition (IV) $1 \mathrm{ml}$ of treated samples from reaction (III) was heated at $120^{\circ} \mathrm{C}$ for $6 \mathrm{~h}$ and overnight at $105^{\circ} \mathrm{C}$ in an oil bath.

\section{Plant cell wall polysaccharides immunoassay}

Commercially available rat mAbs were used to detect specific polysaccharide antigens among the different reaction products (Plant Probes UK Development). JIM5, LM15, LM10 and LM21 mAbs reveal respectively, unesterified homogalacturonans [13], alphaL-xyloglucans [14], unsubstituted and relatively low-substituted xylans [15] and mannan, glucomannan and galactomannan [16]. Polysaccharide standards used as control were pectins (Poly-Dgalacturonic acid methyl ester) from citrus (Sigma-Aldrich), xylans (Poly( $\beta$-D-xylopyranose[1 $1 \rightarrow 4]$ ) from beechwood (Sigma-Aldrich), xyloglucan from tamarin seeds (Megazyme) and guar (Sigma-Aldrich). These standards were either solubilised in water or EMIM-OAc $\left(80^{\circ} \mathrm{C}\right.$, $3 \mathrm{~h}$ ) in an oil bath. For wood polysaccharide quantification, 0.05 to 1 $\mu \mathrm{l}$ of the different IL extracts (protocols I to IV) were diluted in $200 \mu \mathrm{l}$ of water and vacuum-blotted onto nitrocellulose membranes (BioTrace NT, Amersham) with a SRC 96 D manifold blotter (Schleicher and Schuell). After $6 \mathrm{~h}$ of blocking incubation with 5\% skimmed milk in TBS (50 mM Tris- $\mathrm{HCl}, 100 \mathrm{mM} \mathrm{NaCl} \mathrm{pH} \mathrm{7.6)} \mathrm{membrane} \mathrm{replicates}$ were incubated overnight in TBS supplemented with each of the diluted $\mathrm{mAbs}(1 / 100)$. After three washes in TBS, the blots were incubated with alkaline phosphatase (AP) conjugated antirat IgG (1/10 000) in TBS for $1 \mathrm{~h}$. Unfixed secondary antibodies were washed-off three times with TBS and AP activities revealed with $1-$ Step $^{\mathrm{TM}} \mathrm{NBT} / \mathrm{BCIP}$ according to the manufacturer recommendations (Thermo Scientific). Dot-blots were scanned and AP activities quantified using ImageJ64 software (v10.2). Each immunoassay was conducted in triplicates corresponding to three different extractions from the same amount of wood powder.

\section{Conventional plant cell wall polysaccharide fractioning and assays}

Approximately $1.2 \mathrm{~g}$ of wood powder was used as starting material for conventional cell wall fractioning according to the reference method described in [3]. Briefly, four fractions of pectin were obtained by the sequential action of $50 \mathrm{mM}$ cyclohexanediaminetetraacetic acid (CDTA) (B fraction), $50 \mathrm{mM}$ sodium carbonate (C fraction), $50 \mathrm{mM}$ sodium carbonate containing $20 \mathrm{mg} / \mathrm{ml} \mathrm{NaBH}_{4}$ (D fraction) and at last by an endopolygalacturonase enzymatic reaction (E fraction). Enriched hemicellulose fractions were separated by sequential extraction with 1 $\mathrm{M} \mathrm{KOH} \mathrm{(F1} \mathrm{fraction)} \mathrm{and} 4 \mathrm{M} \mathrm{KOH} \mathrm{(F4} \mathrm{fraction).} \mathrm{Molar} \mathrm{carbohydrate}$ composition was determined through monosaccharide quantitation after methanolysis $\left(\mathrm{MeOH} / \mathrm{HCl} 1 \mathrm{~N}, 80^{\circ} \mathrm{C}, 24 \mathrm{~h}\right)$, N-reacetylation and trimethylsilylation by gas liquid chromatography of per-Otrimethylsilylated methylglycosides according to [12] modified by [5] Per-O-trimethylsilylated methyl glycosides were separated through a CPSIL-5CB capillary column $(0.32 \mathrm{~mm} \times 50 \mathrm{~m}$, Chrompack $)$ in a Girdel 300 gas chromatograph and quantified with a flame ionization detector using nitrogen as carrier gas.

\section{Results and Discussion}

Ionic liquids (ILs) are considered as new green solvents and have recently been used to dissolve plant biomass and particularly wood in biofuel production projects [17]. The complete dissolution of red oak and southern yellow pine wood in [Emim]-OAc was shown to require $25 \mathrm{~h}$ and up to $46 \mathrm{~h}$ incubation periods at $110^{\circ} \mathrm{C}$, respectively. For southern yellow pine, the time to achieve complete wood solubilization in IL was reduced to $16 \mathrm{~h}$ thanks to microwave pretreatments (100 pulses of 3 s) [11]. Based on these conclusions, different treatments in [Emim]-OAc associated to either microwave irradiation, heating, or both combined were tested on black walnut wood to dissolve the lignocellulosic material. Heating walnut wood powder for $2 \mathrm{~h}$ at $80^{\circ} \mathrm{C}$ and overnight at $55^{\circ} \mathrm{C}$ led to partial wood dissolution (Figure 1). Interestingly, microwave irradiation alone gave similar results within $6 \mathrm{~min}$ for incubation temperatures limited to 50 or $80^{\circ} \mathrm{C}$ (Figure 1 and III). In the end, a combined microwave irradiation followed by constant heating at $120^{\circ} \mathrm{C}$ for $6 \mathrm{~h}$ and overnight at $105^{\circ} \mathrm{C}$ allowed a complete solubilization of the biomass (Figure IV). Since the solubilized polysaccharides from wood biomass were to be detected with mAbs (LM15, LM10, LM21 and JIM5), a preliminary test of their reactivity against commercial polysaccharides solubilized in IL (pectin methyl ester $[\alpha-D-G a l A p-(1 \rightarrow 4)]_{n}$; xylan $[\beta-D-X y l p-(1 \rightarrow 4)]_{n}$, xyloglucan $[\alpha-D-$ Xylp-( $1 \rightarrow 6)-\beta$-D-Glcp- $(1 \rightarrow 4)]_{n}$ and mannan (guar)) was performed

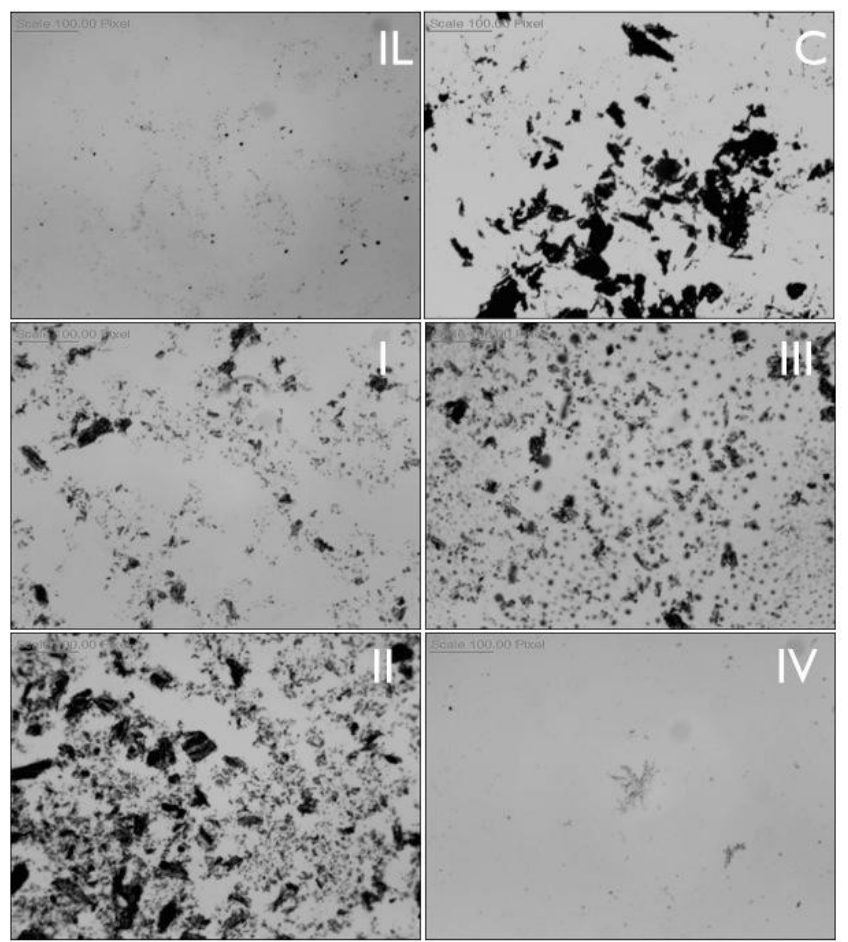

Figure 1:Optical microscopic observations of ionic liquid-wood suspensions. IL: Blank: Ionic liquid ([EMIM]-OAc). C: Control: Wood powder in IL before any treatment. Residual wood particles were then observed after each treatment: I: protocol I $\left(80^{\circ} \mathrm{C}\right.$ for $2 \mathrm{~h}$ and $18 \mathrm{~h}$ at $\left.55^{\circ} \mathrm{C}\right)$. II: protocol II ( 3 microwave irradiations at $300 \mathrm{~W}$ for 2 min with $80^{\circ} \mathrm{C}$ upper limit temperature). III: protocol III (2 microwave irradiations at $300 \mathrm{~W}$ for $30 \mathrm{sec}$ with $50^{\circ} \mathrm{C}$ upper limit temperature followed by 2 more irradiations of $50 \mathrm{sec}$ with $50^{\circ} \mathrm{C}$ upper limit temperature). IV : protocol IV (1 ml of reaction III additionally treated for $6 \mathrm{~h}$ at $120^{\circ} \mathrm{C}$ and $18 \mathrm{~h}$ at $105^{\circ} \mathrm{C}$ ). 
Citation: Plazanet I, Zerrouki R, Lhernould S, Breton C, Costa G (2015) Direct Immunological Detection of Wood Cell Wall Polysaccharides after Microwave-Assisted Ionic Liquid Disruption. J Glycobiol 4: 115. doi:10.4172/2168-958X.1000115

Page 3 of 4

(Figure 2A). Whatever the solvent used - water or [EMIM]-OAc - each $\mathrm{mAb}$ tested remained able to recognize its target epitope on commercial polysaccharide standards. Their detection capacity ranged from 0.1 to $1 \mu \mathrm{g}$ of polysaccharides per dot. Even if the detection ranges are different between water or [EMIM]-OAc solubilized polysaccharides, it is possible to establish calibration curves to quantify their amounts $\left(\mathrm{R}^{2}=0.72\right.$ and 0.99 for JIM5 and LM10, respectively).

Based on these results and in order to further confirm the possibility to use mAbs macroarrays to assay IL solubilized wood polysaccharides, we applied this protocol to the fractions obtained from walnut wood powder treated according to [3] as reference method (Table 1, Figure 2B) and to the (I) to (IV) IL/microwave reaction products (Figure $2 \mathrm{C}$ ). The presence of GalA in $\mathrm{B}, \mathrm{C}, \mathrm{D}$, $\mathrm{E}$ and $\mathrm{F} 1$ fractions suggests the presence of pectic polymers such as homogalacturonan (HG). Indeed, JIM5 epitopes can be found in the same fractions (Figure 2B) as in IL wood solubized assays (Figure 2C). $\mathrm{Xyl}$ and Glc residues are also detected in the F4 fraction suggesting the occurrence of xylan and, probably to a lesser extent, xyloglucan (Table 1). Both of these hemicellulosic polysaccharides are detected with LM10 and LM15 antibodies in fraction F4 (Figure 2B) as well as in IL solubilized wood polysaccharides (Figure 2C). Ultimately, the last hemicellulose polysaccharides tested, mannans (LM21) detected in B and $\mathrm{F} 1$ fractions of the reference method (Figure $2 \mathrm{~B}$ ) are also revealed in each IL treated sample (Figure 2C). Taken together, IL/heat treated samples antibody labelling patterns appear relatively similar to those obtained with the reference extraction method. In switch grass lignin disruption experiments, Socha et al. [18] suggested that an [Emim]-

\begin{tabular}{|l|c|c|c|c|c|c|}
\hline & B & C & D & E & F1 & F4 \\
\hline Ara & 1.03 & 2.39 & 3.45 & 5.7 & 4.5 & 0.3 \\
\hline Rha & 3.54 & 5.87 & 5.89 & 12.54 & 17.56 & 1.9 \\
\hline Fuc & 0 & 1.02 & 0 & 0 & 0 & 0 \\
\hline Xyl & 1.38 & 21.05 & 26.5 & 24.7 & 24.95 & 86.7 \\
\hline Man & 2.99 & 3.51 & 3.58 & 4.58 & 5.6 & 0 \\
\hline Gal & 2.65 & 4.02 & 5.01 & 9.02 & 21.09 & 0.59 \\
\hline GalA & 39.45 & 28.36 & 29.2 & 26.58 & 10.56 & 0.78 \\
\hline Glc & 48.96 & 33.78 & 25.93 & 14.12 & 15.74 & 9.3 \\
\hline GlcA & 0 & 0 & 0.44 & 2.75 & 0 & 0.5 \\
\hline
\end{tabular}

Table 1: Percentage of trimethylsililated monosaccharides obtained from walnut wood powder in the six fractions isolated according to the reference method [3] The different types of monosccharides were separated, identified and quantified by gas chromatography. B to $\mathrm{E}$ : enriched fractions containing pectins; F1 and F4 : enriched fractions containing hemicelluloses.
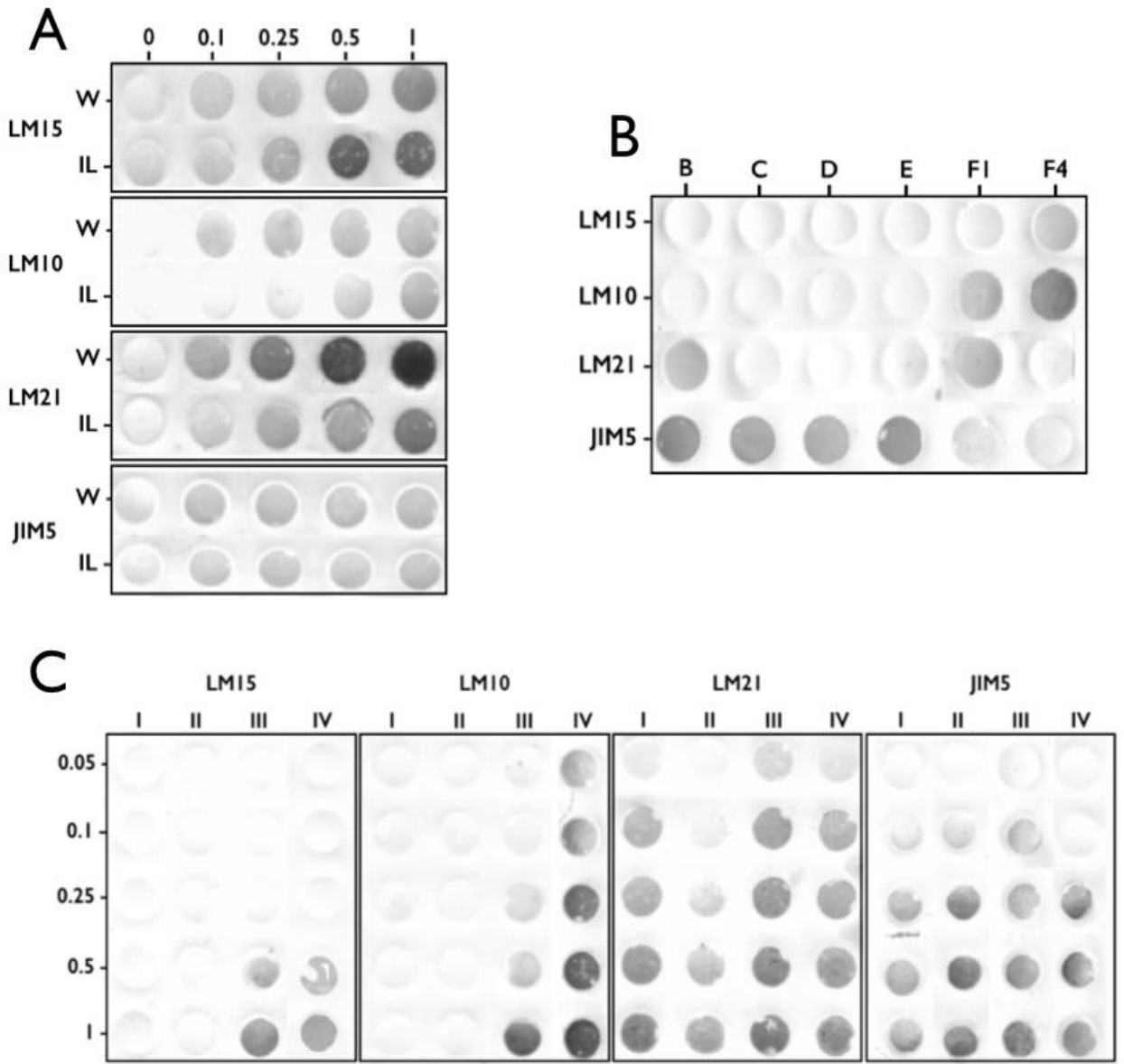

Figure 2: Dot-blot immundetection of polysacharides A. Dot blot of commercially available polysaccharides used as controls. Zero to $1 \mu \mathrm{g}$ of xyloglucan (tamarin seeds), xylans (beechwood), guar and pectins (citrus) were solubilized in water (upper lane) or in IL (lower lane) and spotted onto nitrocellulose membranes before being revealed with LM15, LM10, LM21 and JIM5 mAbs. Two $\mu \mathrm{g}$ of polysaccharides were spotted for LM10 and LM21 and $20 \mu \mathrm{g}$ for LM15 and JIM. B. Dot blot analysis of the walnut wood polysaccharides fractionnated according to Vanzin et al. [3] (same mAbs). Upper line: B to E enriched fractions containing pectins; F1 and F4 enriched fractions containing hemicelluloses. Two $\mu \mathrm{g}$ of polysaccharides were spotted for LM10 and LM21 and $20 \mu \mathrm{g}$ for LM15 and JIM C. IL solubilized walnut wood polysaccharides according to protocols I, II, III and IV. In each column, 0.05 to $1 \mu$ l of crude solution were diluted in $200 \mu \mathrm{I}$ of water, spotted and detected with LM15, LM10, LM21 and JIM5 mAbs. 
OAc pretreatment $\left(3 \mathrm{~h}, 160^{\circ} \mathrm{C}\right)$ could modify polysaccharide epitopes accesibility and, consequently reduce pectin identification and increase hemicellulose detection. However in this protocol, IL-delignification is followed by a water washing step of the residues that could lead to the loss of some pectins since some homogalacturonans and arabinogalactans are water soluble [19]. Our polysaccharide solubilization procedure is based on the use of pure IL and does not involve any washing nor extraction of the samples before being spotted and assayed. We also demonstrate that different walnut wood polysaccharides, including homogalacturonans, can be solubilized in IL while remaining efficiently recognized by a small set of mAbs. Interestingly, only protocol III shows a significant labeling whatever the antibody used. Even though wood dissolution is facilitated by higher temperatures (protocol IV), it has been shown that excessive heating could modify the structure of the released polysaccharides such as cellulose [11]. Thus, an exposure of the samples to a higher temperature $\left(120^{\circ} \mathrm{C}\right)$ in protocol IV could explain both the disappearance of homogalacturonans epitopes and the absence of increase of mannan epitope detection compared to protocol III. In the same manner, a pretreatment of corncob extracts with [Emim]$\mathrm{OAc}$ at $110^{\circ} \mathrm{C}$ during $5 \mathrm{~h}$ did not induce a significant degradation of hemicelluloses [20].

In conclusion, we show here that IL treatment associated with carefully controlled microwave irradiations and temperature exposures allowed us to disrupt complex wood matter in less than $5 \mathrm{~min}$ and release cell wall polysaccharides in a mild enough manner that they remained identifiable by mAbs. In our hands, immunolabeling methods were shown to be as informative as a GC-based method used as reference. Even though immunological analysis are faster, some limitations can be expected due to eventual cross-reactivities of the antibodies as well as their availability in view of the great diversity of cell wall polysaccharides. Despite this, commonly used methods for wood cell wall extractions and analysis are generally highly demanding in technical equipments, skills and require more than 7 days of sample treatment. It is thus very difficult to apply them to large numbers of samples. Using walnut wood, we demonstrate here that IL treatment, microwave irradiation and $\mathrm{mAb}$ macroarray detection can be effectively set-up and used to estimate wood polysaccharide composition twice faster and with 25 times less biological material than a conventional method. This method which could be adapted to different wood material represents an interesting toolkit to analyze of the molecular diversity of polysaccharides from larger populations of woody plants. Indeed, we have recently applied it on douglas fir wood that was totally solubilized in pure [Emim]-OAc in $6 \mathrm{~min}$ by microwave irradiation at temperature below $80^{\circ} \mathrm{C}$. Hemicelluloses (xylans, mannans and xyloglucans) as well as pectins (homogalacturonans and arabinogalactans) were identified in the same manner.

\section{References}

1. Doblin MS, Pettolino F, Bacic A (2010) Plant cell walls: the skeleton of the plant world. Funct Plant Biol 37: 357-381.

2. Mosier N, Wyman C, Dale B, Elander R, Lee YY, et al. (2005) Features of promising technologies for pretreatment of lignocellulosic biomass. Bioresour Technol 96: 673-686.

3. Vanzin GF, Madson M, Carpita NC, Raikhel NV, Keegstra K, et al. (2002) The mur2 mutant of Arabidopsis thaliana lacks fucosylated xyloglucan because of a lesion in fucosyltransferase AtFUT1. Proc Natl Acad Sci U S A 99: 3340 3345.

4. Ruperez P, Selvendran RR, Stevens BJH (1985) Investigation of the heterogeneity of xyloglucans from the cell walls of apple. Carbohydr Res 142: 107-113.

5. Montreuil J, Bouquelet S, Debray H, Fournet B, Spik G, et al. (1986)
Glycoproteins. M F Chaplin, J F Kennedy (Eds.) Carbohydrate analysis: A Practical Approach, Oxford: IRL Press, 143-204.

6. Dardelle F, Lehner A, Ramdani Y, Bardor M, Lerouge P, et al. (2010) Biochemical and immunocytological characterizations of Arabidopsis pollen tube cell wall. Plant Physiol 153: 1563-1576.

7. Moller I, Marcus SE, Haeger A, Verhertbruggen Y, Verhoef R, et al. (2008) High-throughput screening of monoclonal antibodies against plant cell wal glycans by hierarchical clustering of their carbohydrate microarray binding profiles. Glycoconj J 25: 37-48.

8. Pattathil S, Avci U, Baldwin D, Swennes AG, McGill JA, et al. (2010) A comprehensive toolkit of plant cell wall glycan-directed monoclonal antibodies. Plant Physiol 153: 514-525.

9. Welton T (1999) Room-Temperature Ionic Liquids. Solvents for Synthesis and Catalysis. Chem Rev 99: 2071-2084.

10. Swatloski RP, Spear SK, Holbrey JD, Rogers RD (2002) Dissolution of cellulose [correction of cellose] with ionic liquids. J Am Chem Soc 124: 49744975 .

11. Sun N, Rahman M, Qin Y, Maxim ML, Rodríguez H, et al. (2009) Complete dissolution and partial delignification of wood in the ionic liquid 1-ethyl-3methylimidazolium acetate. Green Chem 11: 646-655.

12. Kamerling JP, Gerwig GJ, Vliegenthart JF, Clamp JR (1975) Characterization by gas-liquid chromatography-mass spectrometry and proton-magneticresonance spectroscopy of pertrimethylsilyl methyl glycosides obtained in the methanolysis of glycoproteins and glycopeptides. Biochem J 151: 491-495.

13. Clausen MH, Willats WG, Knox JP (2003) Synthetic methyl hexagalacturonate hapten inhibitors of anti-homogalacturonan monoclonal antibodies LM7, JIM5 and JIM7. Carbohydr Res 338: 1797-1800.

14. Marcus SE, Verhertbruggen $\mathrm{Y}$, Hervé C, Ordaz-Ortiz JJ, Farkas V, et al. (2008) Pectic homogalacturonan masks abundant sets of xyloglucan epitopes in plant cell walls. BMC Plant Biol 8: 60.

15. McCartney L, Marcus SE, Knox JP (2005) Monoclonal antibodies to plant cell wall xylans and arabinoxylans. J Histochem Cytochem 53: 543-546.

16. Marcus SE, Blake AW, Benians TA, Lee KJ, Poyser C, et al. (2010) Restricted access of proteins to mannan polysaccharides in intact plant cell walls. Plant J 64: 191-203

17. Patachiaa SF, Nistorb MT, Vasileb C (2013) Thermal behavior of some wood species treated with ionic liquid. Ind Crops Prod 44: 511-519.

18. Socha AM, Parthasarathi R, Shi J, Pattathil S, Whyte D, et al. (2014) Efficient biomass pretreatment using ionic liquids derived from lignin and hemicellulose. Proc Natl Acad Sci U S A 111: E3587-3595.

19. Deng J, Shi ZJ, Li XZ, Liu HM (2012) Soluble Polysaccharides Isolation and Characterization from Rabbiteye Blueberry (Vaccinium ashei) Fruits. BioResources 8: 405-419.

20. Sun SN, Li MF, Yuan TQ, Xu F, Sun RC (2012) Effect of ionic liquid pretreatment on the structure of hemicelluloses from corncob. J Agric Food Chem 60: 11120-11127.

Submit your next manuscript and get advantages of OMICS Group submissions

Unique features:

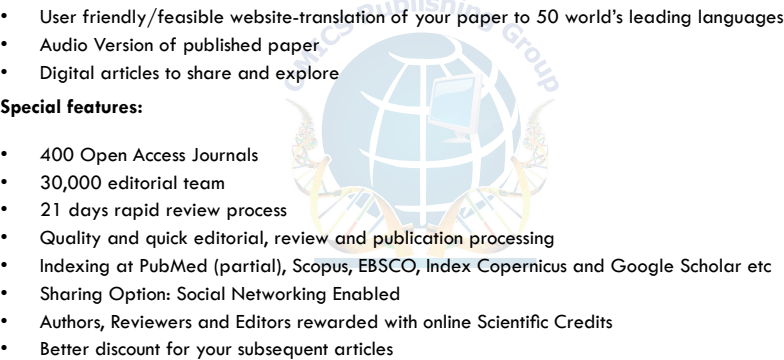

